\title{
Dual action of NSC606985 on cell growth and apoptosis mediated through PKCס in prostatic cancer cells
}

\author{
XIN WANG $^{1,2^{*}}$, CHEN TAN $^{1 *}$, GUO WANG $^{1,2}$, JING-JING CAI $^{1,2}$, LI-PING WANG $^{1,3}$, \\ JULIANNE IMPERATO-McGINLEY ${ }^{1}$ and YUAN-SHAN ZHU ${ }^{1,2}$ \\ ${ }^{1}$ Department of Medicine/Endocrinology, Weill Cornell Medicine, New York, NY 10065, USA; \\ ${ }^{2}$ Xiangya Hospital of Xiangya School of Medicine, Central South University, Changsha, Hunan 410008; \\ ${ }^{3}$ The First People's Hospital of Chenzhou City, University of South China, Chenzhou, Hunan 423000, P.R. China
}

Received June 21, 2017; Accepted September 8, 2017

DOI: 10.3892/ijo.2017.4138

\begin{abstract}
Chemotherapy is a vital therapeutic strategy for castration-resistant prostate cancer (CRPC). We have previously shown that NSC606985 (NSC), a camptothecin (CPT) analog, induced cell apoptosis via interacting with topoisomerase I (Topo I) in prostate cancer cells. In the present study, the effect and mechanism of CPT analogs in LAPC4 cells were investigated. LAPC-4 cells were treated with NSC, $\mathrm{CPT}$, and topotecan. Cell proliferation, apoptosis, and protein kinase $\mathrm{C} \delta(\mathrm{PKC} \delta)$ subcellular activation were measured at different doses and time-points, with or without PKC $\delta$ inhibition or knockdown of PKC $\delta$ expression. NSC at doses ranging from 10 to $100 \mathrm{nM}$ induced a dose-dependent increase in viable cell number and DNA biosynthesis with mild cell apoptosis, whereas, at doses ranging from $500 \mathrm{nM}$ to $5 \mathrm{mM}$, NSC produced a dose-dependent decrease in cell proliferation and DNA biosynthesis with a significant induction of cell apoptosis. Both NSC-induced cell proliferation and apoptosis were blocked by knockdown of PKC $\delta$ with a specific RNAi, or by the co-administration of rottlerin, a PKC $\delta$ inhibitor. Moreover, NSC produced a dose-dependent subcellular activation of PKC $\delta$. The dose-dependent dual action of NSC is mediated at least in part through the differential subcellular activation of PKC $\delta$ in LAPC4 cells. The demonstration of a differential cell response to camptothecin analogs would facilitate the identification of biomarker(s) to CPT sensitivity and promote the personalization of CPT chemotherapy in CRPC.
\end{abstract}

Correspondence to: Dr Yuan-Shan Zhu, Department of Medicine/ Endocrinology, Weill Cornell Medicine, 1300 York Avenue, Box-149, New York, NY 10065, USA

E-mail: yuz2002@med.cornell.edu

Dr Guo Wang, Xiangya Hospital of Xiangya School of Medicine, Central South University, Changsha, Hunan 410008, P.R. China

E-mail: wangguo32@126.com

${ }^{*}$ Co-first authors

Key words: prostate cancer, camptothecin, NSC606985, PKCס, apoptosis, personalized chemotherapy

\section{Introduction}

Prostate cancer ( $\mathrm{PCa})$ is the most common non-cutaneous cancer and the second leading cause of cancer death in American males (1). Despite the initial regression/stabilization brought by androgen deprivation therapy, a large number of $\mathrm{PCa}$ eventually relapses and progresses to castration-resistant prostate cancer (CRPC), with a median survival of only 7-12 months (2), for which, better understanding and newer management is urgently needed. Chemotherapy with new agents such as taxol analogs, and new combinatorial regimens has recently made some progress (3). However, the overall outcome of current chemotherapeutic strategies is still unsatisfactory (4).

Camptothecin (CPT) and its analogs are a promising class of anticancer drugs, which have advanced to the forefront of chemotherapy when used alone or in combination with others (5). CPT inhibits DNA topoisomerase I (Topo I) by blocking the rejoining step of the cleavage/religation reaction, resulting in accumulation of the covalent reaction intermediate, the cleavable complex, which leads to apoptosis and cell cycle arrest (6). The first two CPT derivatives, irinotecan (Camptosar) and topotecan (Hycamtin), were approved by US Food and Drug Administration (FDA) in 1996 for the treatment of colon/rectum cancer, and lung cancer (7). Other analogs, such as exatecan (8), have also shown very promising results in clinical trials. However, the effects of CPT analogs on $\mathrm{PCa}$ are controversial. Most preclinical studies have shown that CPTs are effective for both androgen-dependent and androgen-independent $\mathrm{PCa}(9,10)$. Unfortunately, a couple of clinical trials (phase I/II) with different CPT analogs have only shown very limited benefits on CRPC patients (11-13). Recently, we have demonstrated that NSC606985, a highly water-soluble CPT analog that has rarely been studied for its anticancer activity, produces a significant dose-dependent induction of cell apoptosis at nanomolar concentrations in DU145, LNCaP and PC3 PCa cells (14).

Previous studies have shown that CPT, and apoptotic effects of its analogs may involve protein kinase $\mathrm{C} \delta$ (PKC $\delta$ ) signaling pathway (14-16). PKCD is a member of the serine/threoninespecific PKC family, which has been found to be involved in diverse signaling pathways. From an oncology standpoint, 
PKC $\delta$ is generally considered as an anti-proliferative and proapoptotic protein kinase (17). Previous studies have shown that PKC $\delta$ activates both intrinsic and extrinsic apoptotic pathways in PCa cells under phorbol 12-myristate 13-acetate (PMA) stimulation $(18,19)$. However, recent studies have gradually revealed that $\mathrm{PKC} \delta$ can also function as an anti-apoptotic protein and it is critical for the survival of several cancer cells $(20,21)$. It has been proposed that these apparent opposite actions of PKC $\delta$ are tightly regulated by epigenetic mechanisms including post-translational modifications and cellular compartmentalization (22).

In the present study, we aimed to investigate the effects of CPT analogs, mainly NSC, in LAPC4 cells, elucidate its potential molecular mechanism, and reveal its impact on future CRPC management.

\section{Materials and methods}

Materials. NSC, and topotecan were kindly provided by the Drug Synthesis and Chemistry Branch, Developmental Therapeutic Program, National Cancer Institute (Bethesda, MD, USA). Tissue culture medium, rottlerin, protease inhibitors, propidium iodide (PI), and anti- $\beta$-actin primary antibody were purchased from Sigma-Aldrich (St. Louis, MO, USA). Fetal bovine serum (FBS), L-glutamine, penicillin and streptomycin were from Gemini Bio-Products (Calabasas, CA, USA) Z-VAD-fluoromethylketone (FMK), RNase A, protease $\mathrm{K}$, and M-MLV reverse transcriptase were from Promega (Madison WI, USA). Antibodies against cyclin A, and PKCס were from Santa Cruz Biotechnology, Inc. (Santa Cruz, CA, USA). The cytochrome $c$ antibody (clone 7H8.2C12) was obtained from BD Pharmingen (San Diego, CA, USA). The SYBR-Green Real-Time PCR master mix was from Life Technologies (Grand Island, NY, USA). TriPure Isolation reagent was from Roche Applied Science (Mannheim, Germany).

Cell culture. LAPC4 cells (kindly provided by Dr C. Sawyer) were grown in Iscove's modified Dulbecco's medium supplemented with 15\% FBS, 2 mM L-glutamine, 1 nM R1881, $50 \mathrm{U} / \mathrm{ml}$ of penicillin, and $50 \mu \mathrm{g} / \mathrm{ml}$ of streptomycin. R1881 was withdrawn $48 \mathrm{~h}$ before cell passage to conduct experiments. PC3, LNCaP and DU145 cells (ATCC, Rockville, MD, USA) were grown in RPMI-1640 and Dulbecco's modified Eagle's medium, respectively, supplemented with $10 \%$ FBS, 2 mM L-glutamine, $50 \mathrm{U} / \mathrm{ml}$ of penicillin and $50 \mu \mathrm{g} / \mathrm{ml}$ streptomycin. Cells were maintained in a $5 \% \mathrm{CO}_{2}-95 \%$ air humidified atmosphere at $37^{\circ} \mathrm{C}$, and cultured in phenol red-free medium with $5 \%$ stripped FBS for $24 \mathrm{~h}$ before each experiment. The expression of androgen receptor (AR) was verified with real-time PCR whenever a new vial of LAPC4 was thawed. Treatment with $10 \mathrm{nM}$ dihydrotestosterone was used as a positive control for stimulation of LAPC4 cell growth.

Cell proliferation assays. Cells were seeded in 96-well plates at $\sim 30 \%$ density, and treated with various regimens as indicated in each experiment at $24 \mathrm{~h}$ after plating. The viable cell number was determined using the CellTiter AQueous One Solution Cell Proliferation assay kit from Promega, following the manufacturer's instructions. DNA biosynthesis was determined using the BrdU Cell Proliferation assay kit obtained
Table I. Real-time PCR conditions.

\begin{tabular}{llcr}
\hline Cycle no. & \multicolumn{1}{c}{ Step } & $\begin{array}{c}\text { Temperature } \\
\left({ }^{\circ} \mathrm{C}\right)\end{array}$ & $\begin{array}{r}\text { Time } \\
(\mathrm{sec})\end{array}$ \\
\hline $1 \mathrm{X}$ & UDG incubation & 50 & 120 \\
$1 \mathrm{X}$ & Polymerase activation & 95 & 600 \\
$40 \mathrm{X}$ & Denature & 95 & 15 \\
& Anneal/extend & 60 & 60 \\
$1 \mathrm{X}$ & Melt curve analysis & 95 & 15 \\
& & 55 & 15 \\
& & 95 & 15 \\
\hline
\end{tabular}

UDG, uracil DNA glycosylase.

from Calbiochem (San Diego, CA, USA) following the manufacturer's instructions.

Flow cytometry. Approximately $1 \times 10^{6}$ LAPC4 cells were plated in $60-\mathrm{mm}$ plates and treated with vehicle control or various regimens as indicated in each experiment. At the end of the treatment, cells were collected, washed with phosphate-buffered saline (PBS) and fixed with $70 \%$ ethanol. For DNA content, cells were stained with PI $(50 \mu \mathrm{g} / \mathrm{ml})$ plus RNase A $(20 \mu \mathrm{g} / \mathrm{ml})$ in PBS, and analyzed using the FACScan Flow Cytometer (Becton-Dickinson, Heidelberg, Germany). The data from $1.0 \times 10^{4}$ cells/sample were collected and analyzed using the CellQuest software (Becton-Dickinson). For cell apoptosis analysis, cells were stained with Annexin V in combination with PI using the Annexin V-FITC apoptosis detection kit I from BD Pharmingen according to the manufacturer's instructions.

Determination of DNA fragmentation. NSC treated and untreated cells were harvested and incubated in a lysis buffer [50 mM Tris- $\mathrm{HCl}$ (pH 8.0), $20 \mathrm{mM}$ ethylenediaminetetraacetic acid (EDTA), $10 \mathrm{mM} \mathrm{NaCl}, 1 \%$ sodium dodecyl sulfate (SDS)] for $20 \mathrm{~min}$ on ice. Samples were then centrifuged and treated with DNase-free RNase A and proteinase K. Following phenol and chloroform extraction, DNA was precipitated by ethanol and dissolved in $1 \mathrm{X}$ Tris-EDTA buffer. The DNA samples were then electrophoresed in a $2 \%$ agarose gel, visualized by ethidium bromide staining under ultraviolet light.

Western blot analysis. LAPC4 cells were harvested and total cellular proteins were extracted using a lysis buffer (62.5 mM Tris- $\mathrm{HCl} \mathrm{pH}$ 6.8, $100 \mathrm{mM}$ dithiothreitol, 2\% SDS, $10 \%$ glycerol). The cytosolic, nucleus and mitochondrial protein extracts were prepared as described (14). The protein concentrations were determined using the Bio-Rad Protein assay (Bio-Rad Laboratories, Hercules, CA, USA) following the manufacturer's instructions. Protein $(25 \mu \mathrm{g})$ was loaded in each lane, electrophoresed on a 15\% SDS-PAGE, and transferred to a nitrocellulose membrane (Amersham Pharmacia Biotech, Piscataway, NJ, USA). The blots were blocked with TBST buffer [500 mM NaCl, $20 \mathrm{mM}$ Tris- $\mathrm{HCl}$ (pH 7.4), and $0.1 \%$ Tween-20] containing 5\% nonfat dry milk (Bio-Rad Laboratories) and then incubated with specific primary antibody in TBST buffer containing $1 \%$ nonfat dry milk at $4^{\circ} \mathrm{C}$ 
overnight. Following secondary antibody incubation for $1 \mathrm{~h}$ at room temperature, bands were visualized using a Super Signal Chemiluminescence kit (Millipore, Billerica, MA, USA), and exposed to Kodak X-Max film. $\beta$-actin was used as the internal control after stripping off the original membrane. The images were scanned and relative band intensities were calculated using the NIH ImageJ software.

PKC $\delta$ Steath $^{\mathrm{TM}}$ RNAi transfections. Based upon the sequence of human PRKCD (GenBank ${ }^{\mathrm{TM}}$ accession no. NM_006254), custom steath $^{\mathrm{TM}}$ RNAi oligos (Invitrogen, Carlsbad, CA, USA) at 25-base-pair in length, 5'-CCACUACAUCAAGAACCAU GAGUUU-3' was designed. A non-specific Steath ${ }^{\mathrm{TM}}$ RNAi (NS-RNAi) control, 5'-CCAUGGCGCCAAUUCCAAACAG UUU-3' was also synthesized. All RNAi transfections at doses from 25 to $200 \mathrm{nM}$ were performed using Lipofectamine 2000 (Life Technologies) following the manufacturer's instructions. For the analysis of PKC $\delta$ knockdown following RNAi transfection, LAPC4 cells $\left(5 \times 10^{5}\right.$ cells/well) were seeded in 6-well plates and transfected with various concentrations of RNAi at $24 \mathrm{~h}$ after plating. The cells were harvested at $96 \mathrm{~h}$ of transfection. Total cellular proteins were extracted and subjected to western blot analysis as described above. For cell proliferation and flow cytometric analysis, LAPC4 cells were seeded in 96-well and $60 \mathrm{~mm}$ plates, respectively as described above. Cells were treated with various regimens for $72 \mathrm{~h}$ after $24-\mathrm{h}$ RNAi transfection $(100 \mathrm{nM})$ as indicated in each experiment. Cell proliferation was determined by BrdU assay and cell apoptosis and cell cycle were analyzed by flow cytometry as described above.

Real-Time PCR. Approximately 5x105 LAPC4 cells were seeded in 6-well plates and treated with different regiments, and harvested at different time-points as indicated in each experiment. Total cellular RNA was extracted with TriPure Isolation reagent following the manufacture's instructions. One microgram of RNA per sample was used for reverse transcription using M-MLV reverse transcriptase with RNase inhibitor. Real-time PCR was done with an Eco Real-Time PCR system (Illumina, San Diego, CA, USA). CCNA2 expression level was detected using $2 \mathrm{X} \mathrm{SYBR}{ }^{\mathrm{TM}}$-Green Real-Time PCR master mix. The expression level was normalized with human ACTB using $\Delta \Delta \mathrm{Ct}$ method. The primers used were as follows: for CCNA2 forward, 5'-TGGACCTTCACCAGACCTAC-3' and reverse, 5'-GGTTGAGGAGAGAAACACCA-3'; for ACTB forward, 5'-CTAGAAGCATTTGCGGT GGACGATG-3' and reverse, 5'-TCATGAAGTGTGACGTGG ACATCCG-3'. The final concentration of forward and reverse primer in each reaction system was $200 \mathrm{nM}$, respectively, and the final concentration of total RNA templates was $40 \mathrm{ng} /$ well. The cycling conditions are listed in Table I.

Statistics. The data are presented as mean \pm standard error of the mean. One-way analysis of variance (ANOVA) following post-hoc Student-Newman-Keuls test was used to determine the differences among multiple groups. A p-value $<0.05$ was considered statistically significant. The data and statistical analysis comply with the recommendations on experimental design and analysis in pharmacology (23). All analyses were performed using SigmaPlot 12.0 from Systat Software (Chicago, IL, USA).

\section{Results}

CPT and its analogs produce a dose- and time-dependent dual action on cell growth and death in LAPC4 cells. LAPC4 cells were treated with various doses of CPT and NSC for 24, 48 or 72 h. As shown in Fig. 1A, at 72 h, NSC at doses ranging from 10 to $100 \mathrm{nM}$ produced a dose-dependent increase in viable cell number (1.7-folds of control at $100 \mathrm{nM}, \mathrm{p}<0.01$ ); while at doses ranging from $500 \mathrm{nM}$ to $5 \mu \mathrm{M}$, NSC produced a dose-dependent decrease in viable cell number (0.48-fold of control at $5 \mu \mathrm{M}, \mathrm{p}<0.01)$. This biphasic effect of NSC was also time-dependent (Fig. 1B). An increase in viable cell number was observed at $24 \mathrm{~h}$ and more obvious at 48 and $72 \mathrm{~h}$ with $50 \mathrm{nM}$ NSC treatment, while a time-dependent decrease in viable cell number was observed when cells were treated with $1 \mu \mathrm{M}$ NSC. Similar dose-dependent biphasic effect on viable cell number was observed after $72 \mathrm{~h}$ treatment with CPT (Fig. 1A) and topotecan (Fig. 1C) in LAPC4 cells, although the stimulation by $\mathrm{CPT}$ and topotecan was relatively weaker compared to NSC. Like NSC and CPT (14), topotecan at a low-dose $(50 \mathrm{nM})$ did not stimulate cell growth, while significantly decreased viable cell numbers at a high-dose $(1 \mu \mathrm{M})$ in DU145 and LNCaP cells ( $\mathrm{p}<0.001)$ (Fig. 1C).

Morphological analysis showed that there were more viable cells with higher cell density in NSC $50 \mathrm{nM}$ group than in control group after $72 \mathrm{~h}$ treatment (Fig. 1D). In contrast, $1 \mu \mathrm{M}$ NSC induced significant decrease in cell number with apoptotic characteristics such as shrunken cells and apoptotic bodies (Fig. 1D).

NSC induces apoptosis in LAPC4 cells. To investigate whether the NSC-induced decrease in viable cell number is associated with cell apoptosis, Annexin V/PI staining was performed to determine the apoptotic and/or necrotic cells after NSC treatment in LAPC4. Treatment with NSC produced a time- and dose-dependent increase in early (Annexin $\left.\mathrm{V}^{+} / \mathrm{PI}^{-}\right)$, late apoptotic (Annexin $\mathrm{V}^{+} / \mathrm{PI}^{+}$) and necrotic cells (Annexin $\mathrm{V}^{-} / \mathrm{PI}^{+}$) as shown in Fig. 2A. The fractions of Annexin $\mathrm{V}^{+}$cells were significantly increased at 48 and $72 \mathrm{~h}$ of NSC treatment, and the changes were much greater at $1 \mu \mathrm{M}$ than $50 \mathrm{nM}$ dose. The pro-apoptosis effect was further confirmed by demonstrating that NSC produced a time- and dose-dependent induction of DNA fragmentation (Fig. 2B), and cytosolic cytochrome $c$ release (Fig. 2C).

The dual action of NSC in LAPC4 cells involves PKC $\mathrm{P}$. To investigate whether the NSC-caused dual action involves $\mathrm{PKC} \delta$ activation, rottlerin was used to inhibit $\mathrm{PKC} \delta$ activity. As shown in Fig. 3A, at $1 \mu \mathrm{M}$, rottlerin completely blocked the low-dose $(50 \mathrm{nM}) \mathrm{NSC}$-induced cell growth and significantly rescued the high-dose $(1 \mu \mathrm{M})$ NSC-caused decrease in viable cell number. On the other hand, FMK, a pan-caspase inhibitor, significantly rescued the high-dose NSC-induced decrease in viable cell number without any effect on the low-dose NSC-induced cell growth. Moreover, PKC $\delta$ knockdown by specific RNAi (100 nM) blocked NSC dual action in LAPC4 cells as shown in Fig. 3B. In contract, transfection of an NS-RNAi failed to alter NSC effect on DNA biosynthesis (Fig. 3B). The knockdown of PKC $\delta$ by RNAi transfection was confirmed using western blot analysis (Fig. 3C and D). 

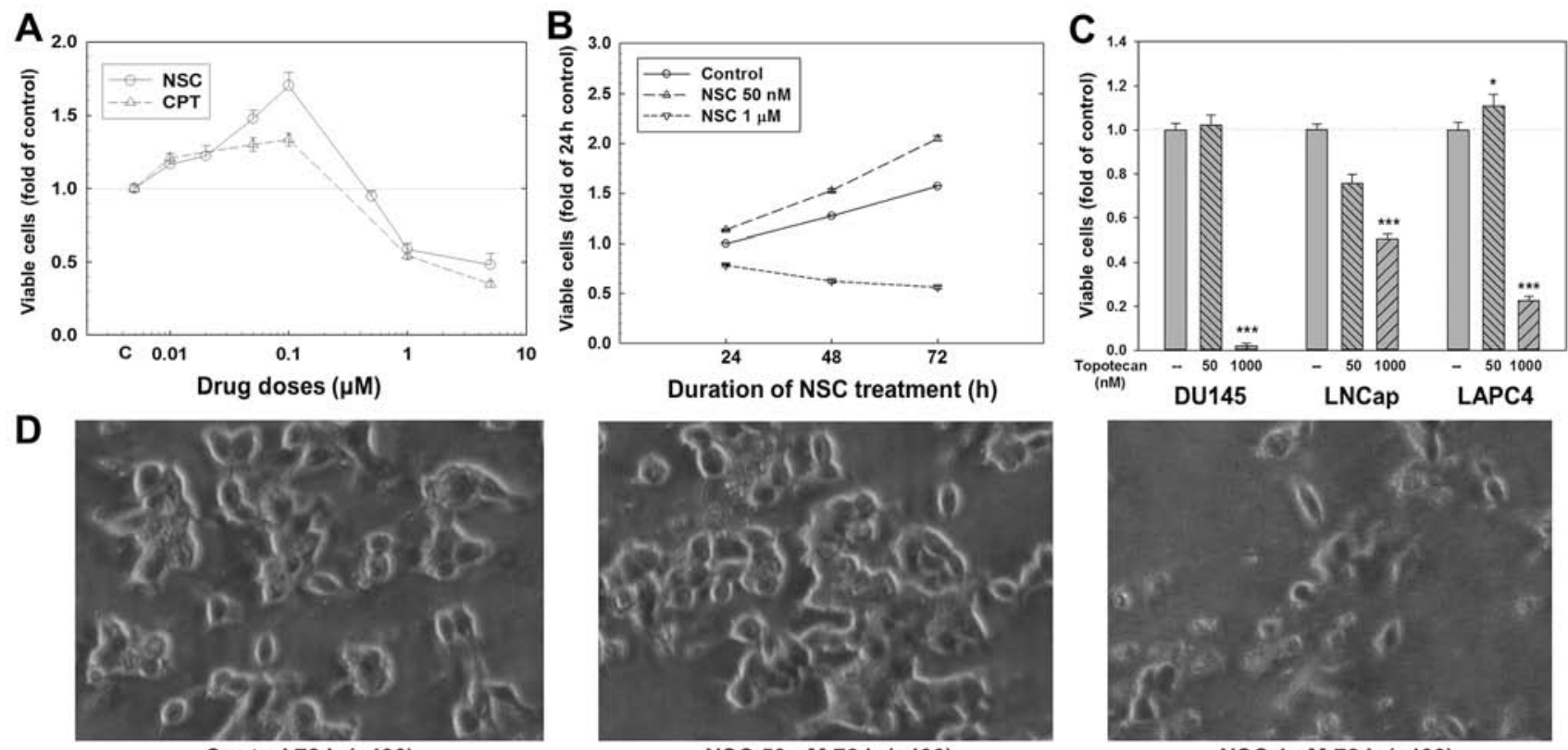

Control $72 \mathrm{~h}(\mathbf{x} 400)$

NSC $50 \mathrm{nM} 72 \mathrm{~h}(\times 400)$

NSC $1 \mu \mathrm{M} 72 \mathrm{~h}(\mathbf{x} 400)$

Figure 1. CPT and its analogs (NSC and topotecan) produce biphasic effect on cell growth and death in PCa cells. (A) Dose-dependent dual action of NSC and CPT on viable cell number in LAPC4 cells after $72 \mathrm{~h}$ treatment. The data are shown as mean \pm SEM, $\mathrm{n}=6-12$ for NSC, $\mathrm{n}=3-6$ for CPT. (B) Time- and dose-dependent dual action of NSC on viable cell number in LAPC4 cells. The data are shown as mean \pm SEM, $(n=3)$. (C) Effects of topotecan treatment for $72 \mathrm{~h}$ on cell viability in different PCa cell lines. The data are shown as mean \pm SEM, $\mathrm{n}=6-9$. (D) Morphological changes of LAPC4 cells after NSC treatment (72 h). ${ }^{*} \mathrm{p}<0.05$ and $^{* *} \mathrm{p}<0.001$ compared to corresponding controls. CPT, camptothecin.

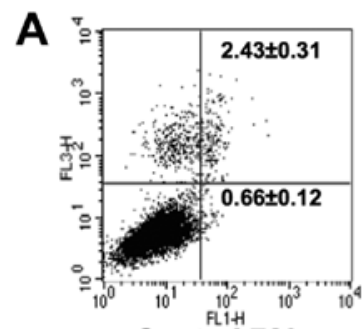

Control $72 \mathrm{~h}$

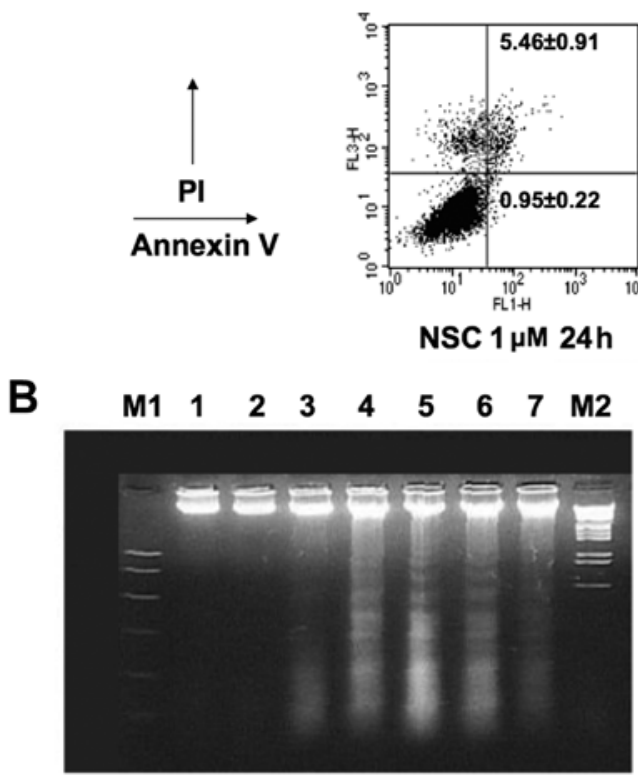

Time (h) $\begin{array}{lllllll}24 & 24 & 48 & 72 & 24 & 48 & 72\end{array}$

C NSC $50 \mathrm{nM}$ NSC $1 \mu \mathrm{M}$
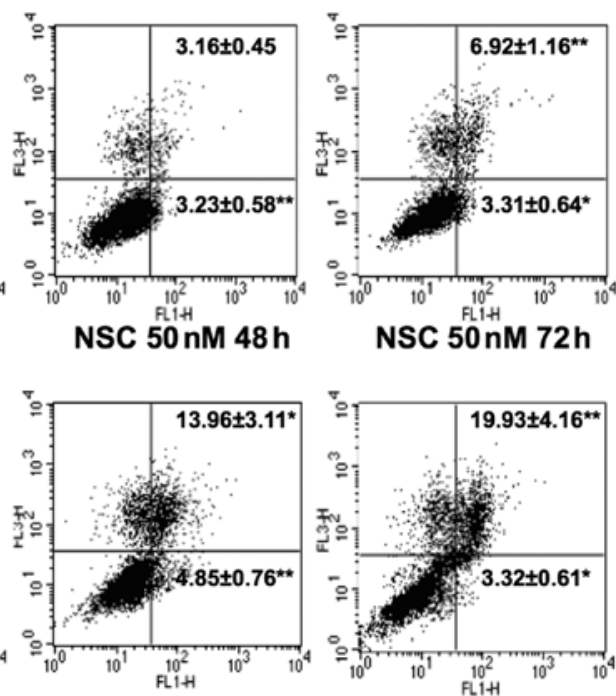

NSC $1 \mu \mathrm{M} 48 \mathrm{~h}$

C

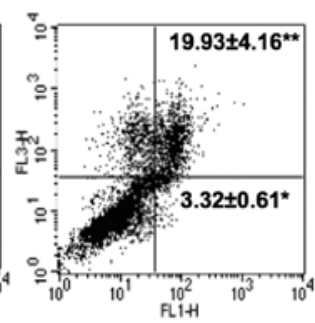

NSC $1 \mu \mathrm{M} 72 \mathrm{~h}$

Mitochondria

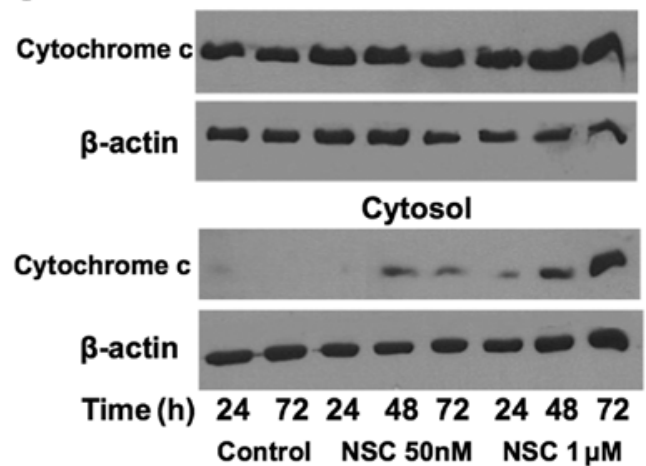

Figure 2. NSC induces cell apoptosis in LAPC4 cells. (A) Time- and dose-dependent apoptosis of LAPC4 cells after NSC treatment. The data are shown as mean \pm SEM, $n=6 .{ }^{*} \mathrm{p}<0.05$ and ${ }^{* *} \mathrm{p}<0.01$ compared to control. (B) NSC induced DNA fragmentation in LAPC4 cells. (C) NSC induced cytochrome $c$ release from mitochondria to cytosol in LAPC4 cells. 
A

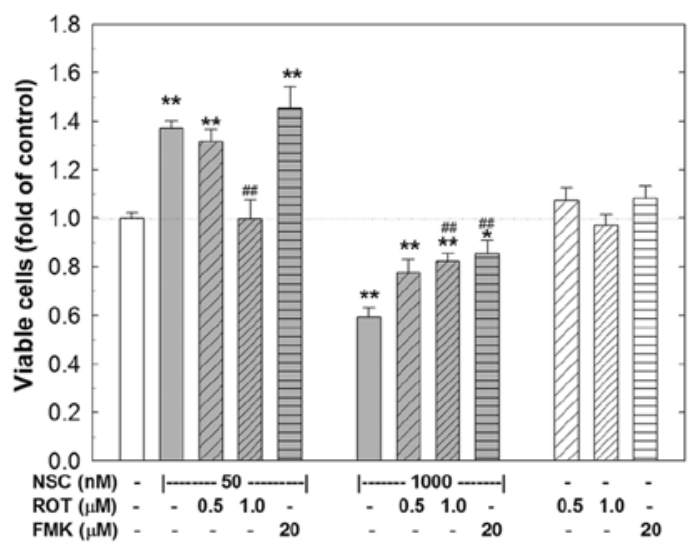

B

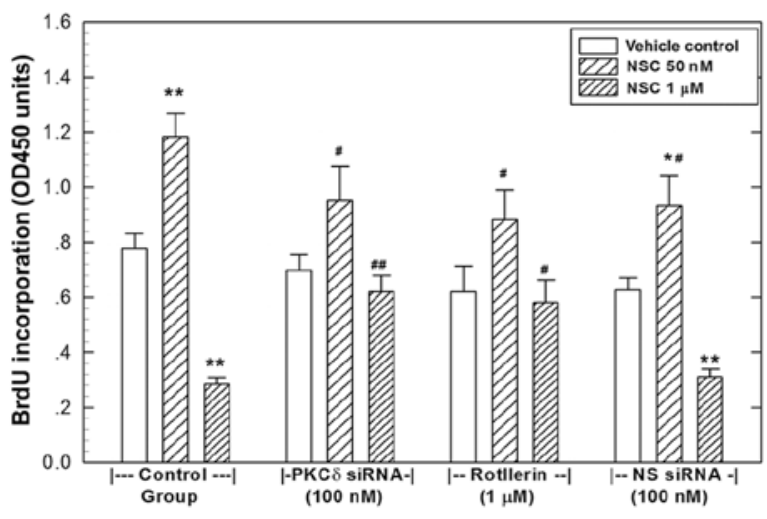

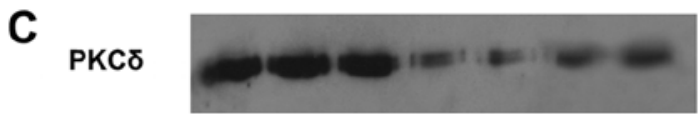

$\beta$-actin

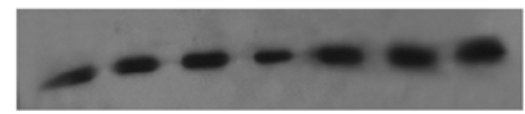

NS RNAi (nM) PKCס RNAi (nM)

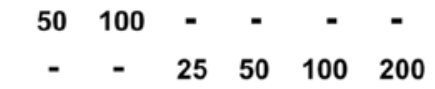

D
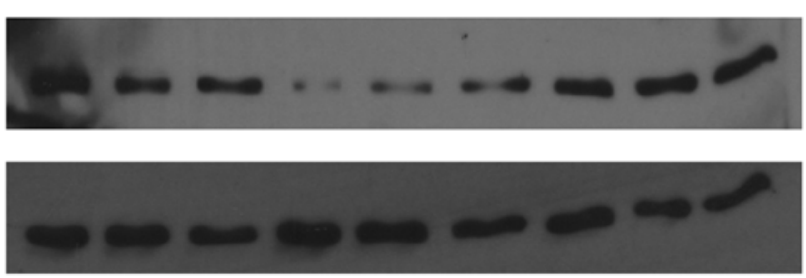

NSC

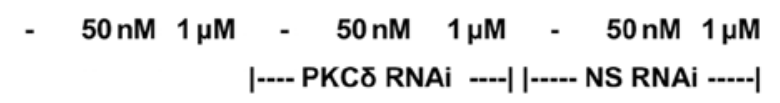

Figure 3. The dual action of NSC involves PKCס in LAPC4 cells. (A) Rottlerin (ROT) blocked NSC-induced biphasic effect in LAPC4 cells. (B) NSC-induced biphasic effect on DNA biosynthesis was blocked by rottlerin and knockdown of PKC $\delta$ in LAPC4 cells. The data in (A and B) are shown as mean \pm SEM, $\mathrm{n}=6-9$. ${ }^{*} \mathrm{p}<0.05$ and ${ }^{* *} \mathrm{p}<0.01$ compared to control; ${ }^{\#} \mathrm{p}<0.01$ compared to corresponding NSC treatment. (C and D) Confirmation of the knockdown of PKC 8 by RNAi transfection with or without NSC treatment. ROT, rottlerin; FMK, Z-VAD-fluoromethylketone; NS RNAi, non-specific RNAi; PKC $\delta$, protein kinase C $\delta$.

A
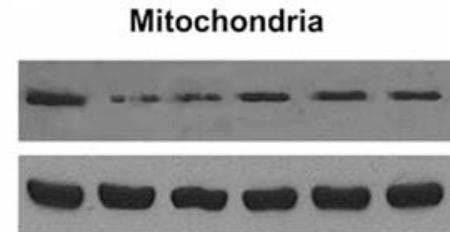

Cytosol

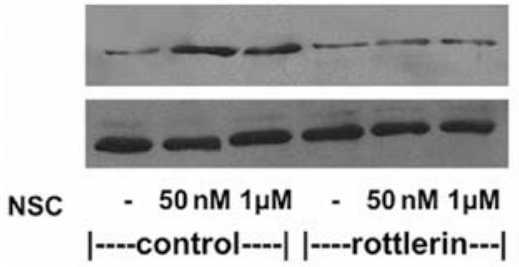

B

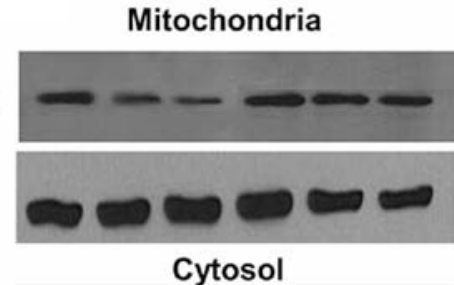

Cytochrome c

$\beta$-actin

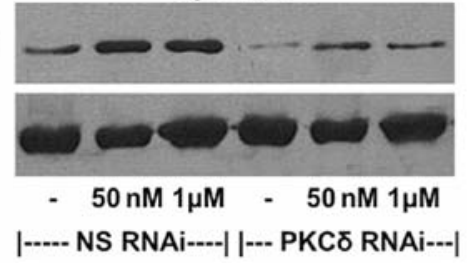

Figure 4. NSC-induced cytochrome $c$ release from mitochondria to cytosol is blocked by rottlerin and knockdown of PKC in LAPC4 cells (72 h). (A) Cytochrome $c$ release after $72 \mathrm{~h}$ NSC treatment with or without co-treatment of rottlerin $(1 \mu \mathrm{M})$. (B) Cytochrome $c$ release after $72 \mathrm{~h}$ NSC treatment with

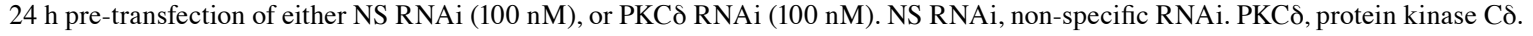

In flow cytometry analysis, as shown in Table II, co-administration of rottlerin at $1 \mu \mathrm{M}$ for $72 \mathrm{~h}$, which did not have any significant impact on cell apoptosis per se, markedly inhibited the NSC-induced apoptosis. PKC $\delta$-knockdown significantly attenuated the $1 \mu \mathrm{M}$ NSC-induced late (Annexin $\mathrm{V}^{+} / \mathrm{PI}^{+}$) and early (Annexin $\mathrm{V}^{+} / \mathrm{PI}^{-}$) apoptotic cells from 19.93 and $3.32 \%$ to 7.81 and $1.68 \%$, respectively (Table II). In contrast, transfection of the NS-RNAi did not significantly affect NSC-induced apoptosis.

Consistent with the inhibition of NSC-induced cell apoptosis, NSC-induced cytochrome $c$ release from mitochondria to cytosol was also greatly attenuated by the co-administration of $1 \mu \mathrm{M}$ rottlerin (Fig. 4A) and the transfection of $100 \mathrm{nM}$ PKC RNAi (Fig. 4B). However, the transfection of an NS-RNAi did not change the NSC-induced cytochrome $c$ release as shown in Fig. 4B.

NSC produces a dose-dependent differential PKC $\delta$ cleavage in subcellular compartments. To explore the potential mechanism of NSC dual action on cell growth and apoptosis, the proteolytic cleavage of PKC $\delta$ in various subcellular compartments were analyzed by western blot analysis. The 
A

\section{PKCס in total cellular extracts}

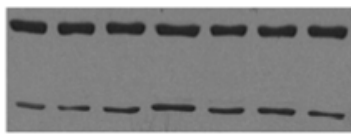

$\begin{array}{lllllll}1.0 & 1.0 & 1.5 & 2.4 & 1.7 & 2.1 & 1.4\end{array}$

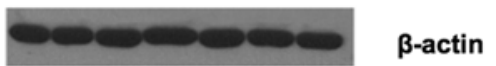

$\begin{array}{lllllllll}72 & 24 & 24 & 48 & 48 & 72 & 72 & \text { Time (h) }\end{array}$

- 501000501000501000 NSC (nM)

C

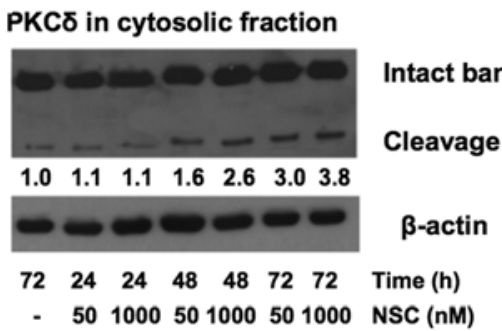

B

PKCס in mitochondrial fraction

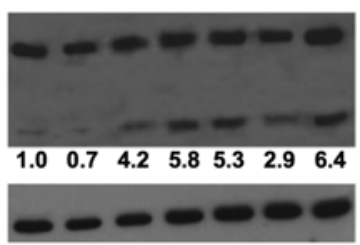

$\begin{array}{llllllll}72 & 24 & 24 & 48 & 48 & 72 & 72 & \text { Time (h) }\end{array}$

- 501000501000501000 NSC (nM)

D

PKCס in nuclear fraction

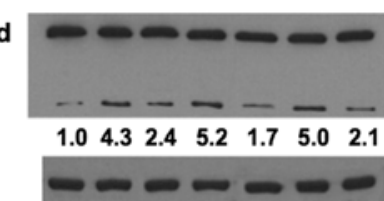

$\begin{array}{lllllllll}72 & 24 & 24 & 48 & 48 & 72 & 72 & \text { Time (h) }\end{array}$

- 501000501000501000 NSC (nM)
E

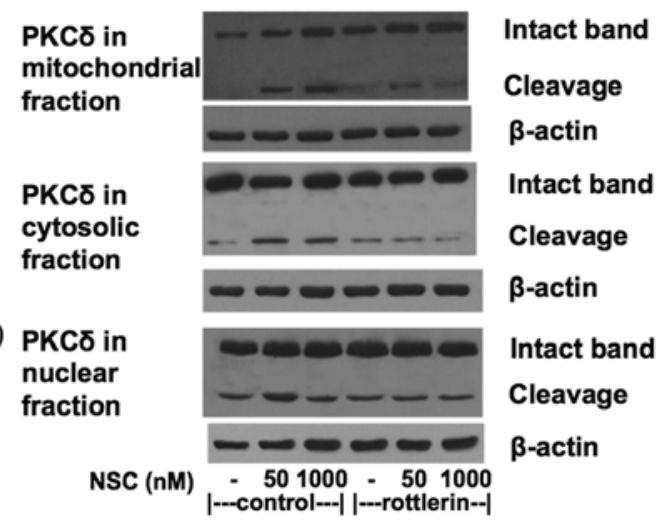

Figure 5. NSC induces proteolytic cleavage of PKCס in a subcellular compartment-specific manner in LAPC4 cells. (A) Total cellular PKC cleavage in LAPC4 cells after NSC treatment. (B) Mitochondrial PKC $\delta$ cleavage in LAPC4 cells after NSC treatment. (C) Cytosolic PKC $\delta$ cleavage in LAPC4 cells after NSC treatment. (D) Nuclear PKC $\delta$ cleavage in LAPC4 cells after NSC treatment. (E) Differential subsellular PKC $\delta$ cleavage in LAPC4 cells after NSC treatment with or without rottlerin $(1 \mu \mathrm{M})$ co-treatment $(72 \mathrm{~h})$. The quantitative changes in PKC $\delta$ cleavage are indicated at the bottom of the PKC $\delta$ western blot analyses (A-D) expressed as folds of control. PKCס, protein kinase C $\delta$.

Table II. Blockade of NSC-induced cell apoptosis by rottlerin and specific PKCס RNAi using flow cytometry analysis (72 h).

\begin{tabular}{|c|c|c|}
\hline Treatment Cell types & $\begin{array}{l}\text { Early apoptotic cells } \\
\left(\text { Annexin } \mathrm{V}^{+} / \mathrm{PI}^{-}\right. \\
\% \text { of total cells) }\end{array}$ & $\begin{array}{l}\text { Late apoptotic cells } \\
\left(\text { Annexin } \mathrm{V}^{+} / \mathrm{PI}^{+},\right. \\
\% \text { of total cells) }\end{array}$ \\
\hline Control & $0.66 \pm 0.12$ & $2.4 \pm 0.31$ \\
\hline NSC $50 \mathrm{nM}$ & $3.31 \pm 0.64^{\mathrm{a}}$ & $6.92 \pm 1.16^{\mathrm{b}}$ \\
\hline $\mathrm{NSC} 1 \mu \mathrm{M}$ & $3.32 \pm 0.61^{\mathrm{a}}$ & $19.93 \pm 4.16^{\mathrm{b}}$ \\
\hline Rottlerin $1 \mu \mathrm{M}$ & $0.66 \pm 0.18$ & $3.91 \pm 0.75$ \\
\hline Rottlerin+NSC $50 \mathrm{nM}$ & $0.13 \pm 0.06$ & $3.94 \pm 0.87^{\mathrm{c}}$ \\
\hline Rottlerin+NSC $1 \mu \mathrm{M}$ & $5.11 \pm 1.28^{\mathrm{b}}$ & $6.81 \pm 1.72^{\mathrm{b}, \mathrm{d}}$ \\
\hline PKCס RNAi & $2.59 \pm 0.81$ & $4.60 \pm 0.81$ \\
\hline PKCס RNAi+NSC $50 \mathrm{nM}$ & $2.97 \pm 0.88$ & $5.91 \pm 0.11$ \\
\hline PKCס RNAi+NSC $1 \mu \mathrm{M}$ & $1.68 \pm 0.43^{\mathrm{d}}$ & $7.81 \pm 1.42^{\mathrm{a}, \mathrm{c}}$ \\
\hline NS RNAi & $4.16 \pm 0.77$ & $5.25 \pm 1.22$ \\
\hline NS RNAi+NSC $50 \mathrm{nM}$ & $5.58 \pm 1.03$ & $9.4 \pm 1.92^{\mathrm{a}}$ \\
\hline NS RNAi+NSC $1 \mu \mathrm{M}$ & $14.85 \pm 3.89^{b}$ & $19.71 \pm 4.50^{\mathrm{b}}$ \\
\hline
\end{tabular}

The data are shown as mean \pm SEM of three independent experiments. ${ }^{a} \mathrm{p}<0.05$ and ${ }^{\mathrm{b}} \mathrm{p}<0.01$ compared to control; ${ }^{\mathrm{c}} \mathrm{p}<0.05$ and ${ }^{\mathrm{d}} \mathrm{p}<0.01$ compared to the corresponding NSC treatment. PKC $\delta$, protein kinase $C \delta$.

total PKCס expression level was not altered with NSC treatment, but a slight increase of PKC $\delta$ cleavage was observed in total cellular protein after NSC treatment as shown in Fig. 5A. Most interestingly, NSC treatment resulted in a dose- and time-dependent differentiated change of PKC $\delta$ proteolytic cleavage in different subcellular compartments as shown in Fig. 5B-D. Treatment with a high-dose $(1 \mu \mathrm{M})$ NSC resulted in a more rapid and robust $\mathrm{PKC} \delta$ cleavage in the membrane/mitochondrial fraction than those treated with a low-dose $(50 \mathrm{nM})$ NSC (Fig. 5B). The level of mitochondrial $\mathrm{PKC} \delta$ cleavage was elevated $>4$-fold at $24 \mathrm{~h}$ of $1 \mu \mathrm{M}$ NSC treatment and sustained for at least $72 \mathrm{~h}$. Similar time-dependent PKC $\delta$ cleavage was observed at either a low or a high-dose NSC treatment in the cytosol (Fig. 5C). Whereas in the nuclear compartment, NSC-induced increase in $\mathrm{PKC} \delta$ cleavage was more rapid, intense and sustainable at low-dose ( $>4$-fold) compared to high-dose treatment ( 2-fold) (Fig. 5D). Moreover, the addition of $1 \mu \mathrm{M}$ rottlerin greatly reduced both the low-dose and highdose NSC-induced proteolytic cleavage of PKC $\delta$ in LAPC4 cells (Fig. 5E). Taken together, these data indicate that NSC produced a dose-dependent differential PKC $\delta$ cleavage in the subcellular compartments of LAPC4 cells.

NSC produces a dose-dependent alteration in cell cycle in LAPC4 cells. Analysis of nuclear DNA distribution showed that NSC produced a time- and dose-dependent increase in hypoploid cells (sub-G1 cells) as shown in Table III, in agreement with the Annexin V/PI staining analysis as described above (Fig. 2A and Table II). The fraction of sub-G1 cells, an important indicator of cell apoptosis, was markedly increased in cells treated with $1 \mu \mathrm{M}$ NSC for $72 \mathrm{~h}$, while it only had slight increase in cells treated with $50 \mathrm{nM} \mathrm{NSC}$ as shown in Table III. NSC at $50 \mathrm{nM}$ produced a significant elevation in the fraction of $\mathrm{G} 2 / \mathrm{M}$ cells. Consistent with the concept that NSC-induced cell apoptosis involves PKC 8 activation, the addition of rottlerin and PKC $\delta$ RNAi transfection both markedly inhibited the high-dose $(1 \mu \mathrm{M})$ NSC-induced sub-G1 cells $(\mathrm{p}<0.01)$ without significant alterations in NSC-induced other cell cycle changes. Whereas, a non-specific RNAi had no effect on NSC-induced cell cycle changes (Table III). 
Table III. NSC-induced cell cycle changes and the blockade by rottlerin and specific PKC $\delta$ RNAi using flow cytometry analysis.

\begin{tabular}{|c|c|c|c|c|}
\hline Treatment & Sub-G1 ( $\%$ of total cells) & G1 (\% of total cells) & $\mathrm{S}$ (\% of total cells) & $\mathrm{G} 2 / \mathrm{M}$ (\% of total cells) \\
\hline Control & $2.54 \pm 0.35$ & $58.74 \pm 2.27$ & $11.07 \pm 0.60$ & $28.63 \pm 1.61$ \\
\hline NSC $50 \mathrm{nM}$ & $4.18 \pm 0.43$ & $45.13 \pm 2.11^{\mathrm{b}}$ & $10.24 \pm 1.16$ & $38.96 \pm 1.88^{\mathrm{a}}$ \\
\hline NSC $1 \mu \mathrm{M}$ & $16.44 \pm 1.63^{\mathrm{b}}$ & $42.28 \pm 2.10^{\mathrm{b}}$ & $17.25 \pm 1.67$ & $23.18 \pm 2.02$ \\
\hline Rottlerin $1 \mu \mathrm{M}$ & $4.60 \pm 0.29$ & $54.78 \pm 2.03$ & $10.31 \pm 1.34$ & $30.62 \pm 1.65$ \\
\hline Rottlerin+NSC $50 \mathrm{nM}$ & $4.87 \pm 0.45$ & $47.28 \pm 1.98^{\mathrm{b}}$ & $10.02 \pm 1.14$ & $37.64 \pm 1.67^{\mathrm{a}}$ \\
\hline Rottlerin+NSC $1 \mu \mathrm{M}$ & $7.14 \pm 0.72^{\mathrm{a}, \mathrm{d}}$ & $41.16 \pm 2.34^{b}$ & $18.31 \pm 1.35$ & $33.77 \pm 1.79$ \\
\hline PKCס RNAi & $3.76 \pm 0.53$ & $53.82 \pm 2.02$ & $11.94 \pm 1.31$ & $32.68 \pm 1.87$ \\
\hline PKCd RNAi+NSC $50 \mathrm{nM}$ & $4.58 \pm 0.45$ & $42.17 \pm 2.01^{\mathrm{b}}$ & $12.73 \pm 1.20$ & $39.54 \pm 1.74^{\mathrm{a}}$ \\
\hline PKCठ RNAi+NSC $1 \mu \mathrm{M}$ & $6.42 \pm 0.74^{\mathrm{a}, \mathrm{d}}$ & $41.5 \pm 2.02^{b}$ & $18.39 \pm 1.55$ & $32.85 \pm 2.07$ \\
\hline NS RNAi & $4.09 \pm 0.48$ & $54.16 \pm 2.06$ & $10.59 \pm 1.32$ & $31.75 \pm 1.61$ \\
\hline NS RNAi+NSC $50 \mathrm{nM}$ & $4.60 \pm 0.57$ & $42.36 \pm 2.12^{b}$ & $13.19 \pm 1.22$ & $38.82 \pm 2.02^{\mathrm{a}}$ \\
\hline NS RNAi+NSC $1 \mu \mathrm{M}$ & $17.35 \pm 1.47^{\mathrm{b}}$ & $42.57 \pm 2.36^{\mathrm{b}}$ & $17.12 \pm 1.46$ & $22.64 \pm 1.52$ \\
\hline
\end{tabular}

LAPC4 cells were treated as indicated for $72 \mathrm{~h}$ and cell cycle was determined by flow cytometry as described in section Materials and methods. The data are shown as mean \pm SEM of three independent experiments. NS RNAi, non-specific RNAi. ${ }^{a} \mathrm{p}<0.05$ and ${ }^{b} \mathrm{p}<0.01$ compared to control; ${ }^{\mathrm{c}} \mathrm{p}<0.05$ and ${ }^{\mathrm{d}} \mathrm{p}<0.01$ compared to the corresponding NSC treatment.
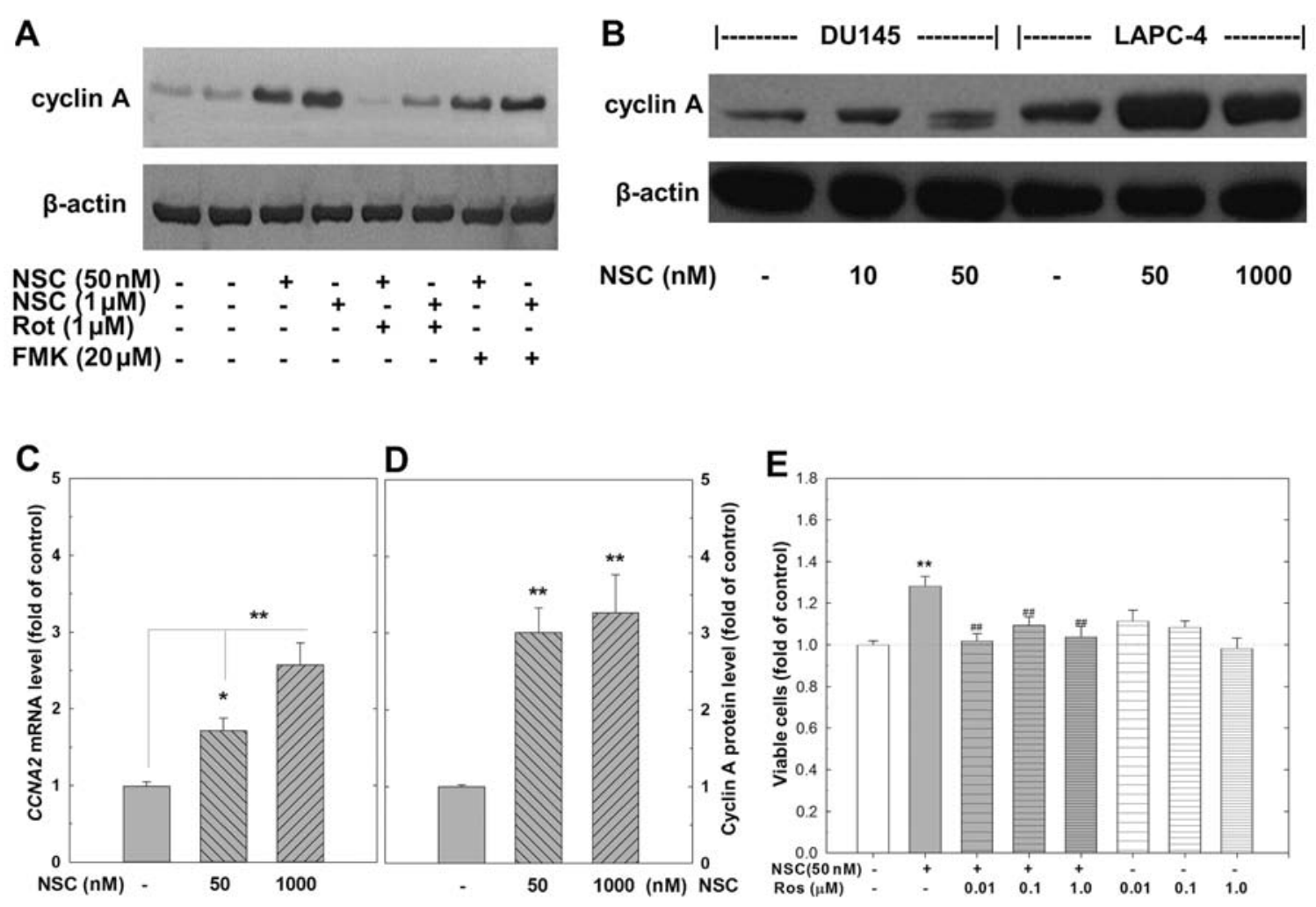

Figure 6. NSC-induced cell growth involves upregulation of cyclin A expression in LAPC4 cells. (A and B) Cyclin A expression in LAPC4 and DU145 cells after $72 \mathrm{~h}$ treatment of various regiments as indicated. (C and D) CCNA2 mRNA and cyclin A protein expression in LAPC4 cells after $72 \mathrm{~h} \mathrm{NSC} \mathrm{treatment,}$ respectively. The data are shown as mean \pm SEM, $n=5-9$. (E) Effects of roscovitine (Ros) on cell growth in NSC-treated (50 nM) LAPC4 cells (72 h). The data are shown as mean $\pm \mathrm{SEM}, \mathrm{n}=6 .{ }^{*} \mathrm{p}<0.05$ and ${ }^{* *} \mathrm{p}<0.01$ compared to control; ${ }^{\# \#} \mathrm{p}<0.01$ compared to NSC treatment alone. ROT, rottlerin; FMK, Z-VADfluoromethylketone; Ros, roscovitine.

NSC-induced cell proliferation is associated with an induction of cyclinA expressionandcyclin-dependent kinaseactivity. The activity of cyclin/cyclin-dependent kinase (CDK) complexes that regulate the progression of cell cycle is controlled by the synthesis of appropriate cyclins during a specific phase of the cell cycle. Western blot analysis demonstrated that treatment with NSC at either a low $(50 \mathrm{nM})$ or a high-dose $(1 \mu \mathrm{M})$ dramatically increased cyclin A expression in LAPC4, but not in DU145 cells (Fig. 6A, B and D). The NSC-induced cyclin A expression was greatly attenuated by rottlerin, but not by FMK (Fig. 6A). RT-PCR analysis confirmed that the levels of CCNA2 mRNA, the somatic type of cyclin A, were 


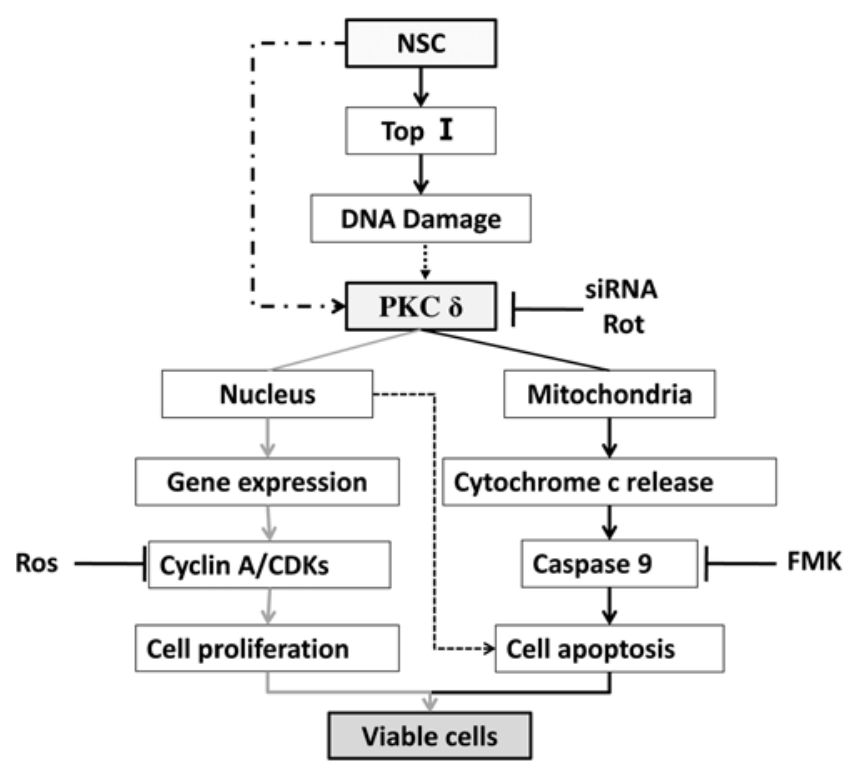

Figure 7. A schematic representation of NSC-induced dual action on cell proliferation and apoptosis in LAPC4 cells. Solid lines indicate defined actions and dashed lines possible actions. Top I, topoisomerase I; Rot, rottlerin; Ros, roscovitine; FMK, Z-VAD-fluoromethylketone; CDKs, cyclin dependent kinases.

significantly elevated at $72 \mathrm{~h}$ of NSC treatment as shown in Fig. 6C. Co-administration of roscovitine (ROS), a selective CDKs inhibitor, at doses ranging from 0.01 to $1 \mu \mathrm{M}$ completely blocked the low-dose NSC $(50 \mathrm{nM})$ inducing cell growth in LAPC4 cells (Fig. 6E).

\section{Discussion}

CPT, a unique pentacyclic quinoline alkaloid isolated from Camptotheca acuminate (24), a native tree from Tibet, China, is one of the prominent leading compounds in anticancer drug development (6). Unfortunately, CPT analogs have only shown limited benefits in the treatment of CRPC (11-13). Previous studies indicate that NSC, a synthetic CPT analogue, induces cell apoptosis and growth inhibition in PCa cells (14), leukemia cells (16), and ovarian cancer cells (25) through an activation of the intrinsic apoptotic pathway and induction of cell cycle arrest. In the present study, we demonstrated, for the first time, that both CPT and its analogs such as NSC and topotecan produced a dose-dependent dual action on cell growth and cell apoptosis in LAPC4 PCa cells (Fig. 1). At low-doses (10-100 $\mathrm{nM})$, both CPT and its analogs produced an overall favorable effect on cell proliferation, whereas, at high-doses (500 nM-5 $\mu \mathrm{M}$ ), CPT and its analogs predominately caused cell apoptosis. Using NSC as an example, we further demonstrated that this dual action was mediated, at least in part, via PKC $\delta$ activation on both ends. This conclusion is supported by the results that co-administration of rottlerin, or transfection of PKC 8 RNAi, both significantly inhibited the proliferative effect induced by low-dose NSC (Fig. 3A-B), and blocked the apoptotic effect induced by high-dose NSC (Figs. 3A and B and 4 and Table II).

PKC $\delta$ is abundantly expressed in mammalian tissues, and has been proved to be involved in the regulation of both intrinsic and extrinsic apoptosis for a wide range of stimuli through various cell-type specific pathways $(18,26)$. It can be activated mainly by four mechanisms, one of which is proteolytic cleavage $(22,27)$. Generally, when the intrinsic/mitochondrial apoptosis pathway is induced by cell stress such as DNA damage by UV, cisplatin and CPT analogs, PKC $\delta$ can be proteolytically cleaved by caspase-3 into a $38 \mathrm{kDa}$ regulatory fragment, and a $41 \mathrm{kDa}$ constantly activated catalytic fragment which translocates to mitochondria, leading to an amplification of the apoptosis cascade in various cell types (27-30). Furthermore, PKC $\delta$ also acts as a 'gatekeeper' to inhibit cell cycle progression through G1/S and G2/M checkpoints by mediating p21CIP1, a G1 CDK inhibitor, and decreasing the expression of cyclins (31). Our previous studies in leukemic cells have demonstrated that NSC rapidly induces the proteolytic activation of PKC $\delta$ with a loss of mitochondrial transmembrane potential $(\Delta \psi \mathrm{m})$ and caspase-3 activation, which is completely blocked by co-administration of rottlerin (16). In the present study, we have demonstrated that NSC produced a time- and dose-dependent induction of cell apoptosis (Fig. 2) and PKCס proteolytic activation (Fig. 5) in LAPC4 cells. These NSC-induced changes were blocked by co-administration of rottlerin or knockdown of PKC $\delta$ with a specific RNAi (Figs. 3, 4 and 5 and Tables II and III). Our results suggest that NSC induced DNA damage and PKC $\delta$ proteolytic activation, leading to an activation of the intrinsic apoptosis pathway in LAPC4 cells.

Most surprisingly, for the very first time, we found that both CPT and CPT analogs (NSC and topotecan) induced cell growth in LAPC4 cells at nanomolar doses. Unlike the NSC-induced apoptotic effect, this proliferative effect of NSC was involved in PKC 8 , but not caspase activation (Figs. 3 and 6). Although PKC $\delta$ has long been proposed as a pro-apoptotic gene and a tumor suppressor, growing evidence suggests that it is also involved in cell proliferation and survival pathways $(21,32,33)$. PKC $\delta$ activation has been reported to induce the insulin-like growth I factor (IGF-I) proliferative signaling in renal carcinoma cells (34), increase the anchorage-independent growth of metastatic breast cancer cells (35), and be correlated with reduced overall breast cancer patient survival (36). In contrast, downregulation of PKC $\delta$ in breast cancer cells results in impairment in cell survival and a potentiation of chemotherapeutic agent-induced apoptosis (37). Although not fully understood, PKC $\delta$ has been reported to regulate multiple molecular signal pathways including NF- $\kappa \mathrm{B}$, Akt-PI3K, mTOR, and Ras/Raf/MEK/ MAPK mitogenic signal transduction pathways $(20,21,38)$, which may lead to cell survival and proliferation. In the present study, we demonstrated that NSC greatly induced cyclin A expression in LAPC4 cells (Fig. 6), a well-known factor in accelerating cell proliferation via interacting with CDK2 (39). The NSC-induced cyclin A expression was associated with NSC-induced cell growth since roscovitine, a specific CDK inhibitor, completely blocked NSC-induced cell growth (Fig. 6E). Moreover, rottlerin, but not FMK, completely blocked NSC-induced cyclin A expression and cell growth, indicating that $\mathrm{PKC} \delta$ activation is upstream of cyclin A expression (Fig. 6A). The NSC-induced cyclin A upregulation was not observed in DU145 cells, consistent with our precious study (14), in which we revealed a potent apoptotic but not proliferative effect of NSC in DU145 
cells, indicating a cell-dependent differential effect of NSC in PCa cells. Taken together, our data strongly indicate that administration of NSC in LAPC4 cells produced a proteolytic activation of PKCS leading to an upregulation of cyclin A, resulting in a promotion of cell survival and proliferation (Fig. 7). We therefore, for the first time, demonstrated that $\mathrm{PKC} \delta$ activation is associated with both cell proliferation and apoptosis in the same cell line.

It is intriguing why PKC activation by NSC results in this dose-dependent biphasic effect. This unconventional doseresponse effect has traditionally been attributed to a functional antagonism model, which proposed that the drug interacts with two independent receptor-effector systems, causing effects that counteract each other in the same system (40-42). The overall outcome would therefore be governed by the sum of the two independent dose-response effects. However, unlike the two independent systems predicted in the model, we observed that the stimulation of both cell proliferation and apoptosis involve PKC $\delta$ activation. We have therefore hypothesized that this NSC biphasic effect may be mediated through a differential activation of PKCS in subcellular compartments. This hypothesis is supported by our demonstration that a low-dose $(50 \mathrm{nM})$ of NSC predominately increased the proteolytic PKC $\delta$ cleavage in nuclei, while a high-dose $(1 \mu \mathrm{M})$ of NSC mainly induced PKC $\delta$ cleavage in mitochondria (Fig. 5). Although the functional significance of this subcellular differential activation of PKCס remains to be elucidated, this is in agreement with previous demonstrations that $\mathrm{PKC} \delta$ activation in mitochondria causes cell apoptosis $(28,30)$, while its activation in nuclei may induce cell proliferation (43). Studies have shown that PKCס nucleic translocation is a central step mediating IGF-I-induced mitogenic and proliferative signaling in primary human skeletal cells (43), and in hypoxia-induced cell proliferation and differentiation in human lung epithelial cells (44). Based on previous studies and our present data, we propose that the dose-dependent biphasic effect of NSC on LAPC4 cells is an integration of cell proliferation and cell apoptosis induced by the differential subcellular activation of PKC $\delta$ as illustrated in Fig. 7. At low-doses of NSC, PKC $\delta$ activity is predominately elevated in the nucleus, presumably due to a relatively low-level DNA damage, leading to a more prominent upregulation of pro-proliferation genes such as cyclin A and consequently cell growth. On the other hand, PKC $\delta$ activation is dramatically increased in the mitochondrion at high NSC doses, presumably due to a higher level DNA damage, which leads to a more prominent activation of the intrinsic apoptotic pathway, outweighs its proliferative effect, and eventually causes cell death.

Finally, the biological and clinical significance of differential response to CPT analogs among PCa cells should not be underestimated. Among the cell lines tested, we have observed that the order of cell sensitivity to NSC-induced cell death is DU145 > PC3 > LNCaP > LAPC4 (14). DU145 cells are the most sensitive PCa cells to NSC with a dramatic apoptosis and cell death at nanomolar concentrations. However, at the same concentration, NSC and topotecan significantly induced cell viability in LAPC4 cells (Fig. 1). Moreover, unlike the molecular alterations observed in LAPC4 cells, NSC neither activates PKCס (14), nor alters cyclin A expression (Fig. 6B) in DU145 cells. This cell-differential effect suggests that the response of individual patients to CPT chemotherapy is variable, which may account, at least in part, for the failure of CPT-related clinical trials in PCa patients (11-13).

In conclusion, the present study demonstrates that CPT and its analogs, such as NSC and topotecan, produce a dose-dependent biphasic effect on cell growth and apoptosis in LAPC4 PCa cells, which may be mediated through a differential subcellular activation of $\mathrm{PKC} \delta$. This atypical biphasic effect of CPT analogs has clear cell specificity. The differential response of different prostate cancer cells to CPT analogs underscores the importance of identifying specific biomarker(s) associated with drug sensitivity, which will guide clinical trials and patient management, leading to an individualized chemotherapy for PCa patients.

\section{Acknowledgements}

We are very grateful to Dr Charles Sawyer (Memorial Sloan-Kettering Cancer Center) for the LAPC4 cells. This study is supported in part by grants from the National Institute of Health (no. UL1-TR000457), the Argenbright Research Fund and the Cohen Research Fund.

\section{References}

1. Siegel R, Ma J, Zou Z and Jemal A: Cancer statistics, 2014. CA Cancer J Clin 64: 9-29, 2014.

2. Petrylak DP: The treatment of hormone-refractory prostate cancer: Docetaxel and beyond. Rev Urol 8 (Suppl 2): S48-S55, 2006.

3. Silvestris N, Leone B, Numico G, Lorusso V and De Lena M: Present status and perspectives in the treatment of hormonerefractory prostate cancer. Oncology 69: 273-282, 2005.

4. Aziz MH, Dreckschmidt NE and Verma AK: Plumbagin, a medicinal plant-derived naphthoquinone, is a novel inhibitor of the growth and invasion of hormone-refractory prostate cancer. Cancer Res 68: 9024-9032, 2008.

5. Frese S, Schüller A, Frese-Schaper M, Gugger M and Schmid RA: Cytotoxic effects of camptothecin and cisplatin combined with tumor necrosis factor-related apoptosis-inducing ligand (Apo2L/TRAIL) in a model of primary culture of non-small cell lung cancer. Anticancer Res 29: 2905-2911, 2009.

6. Legarza K and Yang LX: Novel camptothecin derivatives. In Vivo 19: 283-292, 2005.

7. Srivastava V, Negi AS, Kumar JK, Gupta MM and Khanuja SP: Plant-based anticancer molecules: A chemical and biological profile of some important leads. Bioorg Med Chem 13: 5892-5908, 2005.

8. National Cancer (NC) Institute: NCI Drug Dictionary. https://www.cancer.gov/publications/dictionaries/cancer-drug.

9. Hörmann V, Kumi-Diaka J, Durity M and Rathinavelu A: Anticancer activities of genistein-topotecan combination in prostate cancer cells. J Cell Mol Med 16: 2631-2636, 2012.

10. Minelli R, Cavalli R, Ellis L, Pettazzoni P, Trotta F, Ciamporcero E, Barrera G, Fantozzi R, Dianzani C and Pili R: Nanospongeencapsulated camptothecin exerts anti-tumor activity in human prostate cancer cells. Eur J Pharm Sci 47: 686-694, 2012.

11. Klein CE, Tangen CM, Braun TJ, Hussain MH, Peereboom DM, Nichols CR, Rivkin SE, Dakhil SR and Crawford ED: SWOG-9510: evaluation of topotecan in hormone refractory prostate cancer: a Southwest Oncology Group study. Prostate 52: 264-268, 2002.

12. Reese DM, Tchekmedyian S, Chapman Y, Prager D and Rosen PJ: A phase II trial of irinotecan in hormone-refractory prostate cancer. Invest New Drugs 16: 353-359, 1998-1999.

13. Hudes GR, Kosierowski R, Greenberg R, Ramsey HE, Fox SC, Ozols RF, McAleer CA and Giantonio BJ: Phase II study of topotecan in metastatic hormone-refractory prostate cancer. Invest New Drugs 13: 235-240, 1995.

14. Tan C, Cai LQ, Wu W, Qiao Y, Imperato-McGinley J, Chen GQ and Zhu YS: NSC606985, a novel camptothecin analog, induces apoptosis and growth arrest in prostate tumor cells. Cancer Chemother Pharmacol 63: 303-312, 2009. 
15. Albihn A, Mo H, Yang Y and Henriksson M: Camptothecininduced apoptosis is enhanced by Myc and involves PKCdelta signaling. Int J Cancer 121: 1821-1829, 2007.

16. Song MG, Gao SM, Du KM, Xu M, Yu Y, Zhou YH, Wang Q, Chen Z, Zhu YS and Chen GQ: Nanomolar concentration of NSC606985, a camptothecin analog, induces leukemic-cell apoptosis through protein kinase Cdelta-dependent mechanisms. Blood 105: 3714-3721, 2005.

17. Parker PJ and Murray-Rust J: PKC at a glance. J Cell Sci 117: 131-132, 2004.

18. Gonzalez-Guerrico AM and Kazanietz MG: Phorbol ester-induced apoptosis in prostate cancer cells via autocrine activation of the extrinsic apoptotic cascade: A key role for protein kinase C delta. J Biol Chem 280: 38982-38991, 2005.

19. Yin L, Bennani-Baiti N and Powell CT: Phorbol ester-induced apoptosis of C4-2 cells requires both a unique and a redundant protein kinase C signaling pathway. J Biol Chem 280: 5533-5541, 2005.

20. Jackson DN and Foster DA: The enigmatic protein kinase Cdelta: Complex roles in cell proliferation and survival. FASEB J 18 627-636, 2004

21. Basu A and Pal D: Two faces of protein kinase C $\delta$ : The contrasting roles of PKC $\delta$ in cell survival and cell death. Sci World J 10: 2272-2284, 2010.

22. Steinberg SF: Distinctive activation mechanisms and functions for protein kinase Cdelta. Biochem J 384: 449-459, 2004.

23. Curtis MJ, Bond RA, Spina D, Ahluwalia A, Alexander SP Giembycz MA, Gilchrist A, Hoyer D, Insel PA, Izzo AA, et al: Experimental design and analysis and their reporting: New guidance for publication in BJP. Br J Pharmacol 172: 3461-3471, 2015.

24. Afzal O, Kumar S, Haider MR, Ali MR, Kumar R, Jaggi M and Bawa S: A review on anticancer potential of bioactive heterocycle quinoline. Eur J Med Chem 97: 871-910, 2015.

25. Zhang N, Zhang H, Xia L, Zheng Y, Yu Y, Zhu Y, Chen G and Di W: NSC606985 induces apoptosis, exerts synergistic effects with cisplatin, and inhibits hypoxia-stabilized HIF-1alpha protein in human ovarian cancer cells. Cancer Lett 278: 139-144, 2009.

26. Gavrielides MV, Gonzalez-Guerrico AM, Riobo NA and Kazanietz MG: Androgens regulate protein kinase Cdelta transcription and modulate its apoptotic function in prostate cancer cells. Cancer Res 66: 11792-11801, 2006.

27. Zhao M, Xia L and Chen GQ: Protein kinase $c \delta$ in apoptosis: A brief overview. Arch Immunol Ther Exp (Warsz) 60: 361-372, 2012.

28. Majumder PK, Pandey P, Sun X, Cheng K, Datta R, Saxena S, Kharbanda $S$ and Kufe D: Mitochondrial translocation of protein kinase $\mathrm{C}$ delta in phorbol ester-induced cytochrome $c$ release and apoptosis. J Biol Chem 275: 21793-21796, 2000.

29. Li L, Lorenzo PS, Bogi K, Blumberg PM and Yuspa SH: Protein kinase Cdelta targets mitochondria, alters mitochondrial membrane potential, and induces apoptosis in normal and neoplastic keratinocytes when overexpressed by an adenoviral vector. Mol Cell Biol 19: 8547-8558, 1999.

30. Sumitomo M, Ohba M, Asakuma J, Asano T, Kuroki T, Asano T and Hayakawa M: Protein kinase Cdelta amplifies ceramide formation via mitochondrial signaling in prostate cancer cells. J Clin Invest 109: 827-836, 2002.
31. Toyoda M, Gotoh N, Handa $\mathrm{H}$ and Shibuya M: Involvement of MAP kinase-independent protein kinase $\mathrm{C}$ signaling pathway in the EGF-induced p21(WAF1/Cip1) expression and growth inhibition of A431 cells. Biochem Biophys Res Commun 250: 430-435, 1998

32. Mauro LV, Grossoni VC, Urtreger AJ, Yang C, Colombo LL, Morandi A, Pallotta MG, Kazanietz MG, Bal de Kier Joffé ED and Puricelli LL: PKC Delta (PKCdelta) promotes tumoral progression of human ductal pancreatic cancer. Pancreas 39: e31-e41, 2010.

33. Clark AS, West KA, Blumberg PM and Dennis PA: Altered protein kinase $\mathrm{C}(\mathrm{PKC})$ isoforms in non-small cell lung cancer cells: PKCdelta promotes cellular survival and chemotherapeutic resistance. Cancer Res 63: 780-786, 2003

34. Datta K, Nambudripad R, Pal S, Zhou M, Cohen HT and Mukhopadhyay D: Inhibition of insulin-like growth factor-I-mediated cell signaling by the von Hippel-Lindau gene product in renal cancer. J Biol Chem 275: 20700-20706, 2000.

35. Kiley SC, Clark KJ, Duddy SK, Welch DR and Jaken S: Increased protein kinase $\mathrm{C}$ delta in mammary tumor cells: Relationship to transformtion and metastatic progression. Oncogene 18: 6748-6757, 1999.

36. McKiernan E, O'Brien K, Grebenchtchikov N, Geurts-Moespot A, Sieuwerts AM, Martens JW, Magdolen V, Evoy D, McDermott E, Crown J, et al: Protein kinase Cdelta expression in breast cancer as measured by real-time PCR, western blotting and ELISA. Br J Cancer 99: 1644-1650, 2008.

37. McCracken MA, Miraglia LJ, McKay RA and Strobl JS: Protein kinase $\mathrm{C}$ delta is a prosurvival factor in human breast tumor cell lines. Mol Cancer Ther 2: 273-281, 2003.

38. Kumar V, Pandey P, Sabatini D, Kumar M, Majumder PK, Bharti A, Carmichael G, Kufe D and Kharbanda S: Functional interaction between RAFT1/FRAP/mTOR and protein kinase cdelta in the regulation of cap-dependent initiation of translation. EMBO J 19: 1087-1097, 2000.

39. De Boer L, Oakes V, Beamish H, Giles N, Stevens F, SomodevillaTorres M, Desouza C and Gabrielli B: Cyclin A/cdk2 coordinates centrosomal and nuclear mitotic events. Oncogene 27: 4261-4268, 2008.

40. Ariens EJ, Simonis AM and Van Rossum JM: Theory and experiments concerning the effects of drugs. Pharm Weekbl 91: 617-635, 1956 (In Dutch).

41. Szeto HH, Zhu YS, Umans JG, Dwyer G, Clare S and Amione J: Dual action of morphine on fetal breathing movements. J Pharmacol Exp Ther 245: 537-542, 1988.

42. Zhu YS and Szeto HH: Morphine-induced tachycardia in fetal lambs: A bell-shaped dose-response curve. J Pharmacol Exp Ther 249: 78-82, 1989.

43. Czifra G, Tóth IB, Marincsák R, Juhász I, Kovács I, Acs P, Kovács L, Blumberg PM and Bíró T: Insulin-like growth factor-I-coupled mitogenic signaling in primary cultured human skeletal muscle cells and in $\mathrm{C} 2 \mathrm{C} 12$ myoblasts. A central role of protein kinase Cdelta. Cell Signal 18: 1461-1472, 2006.

44. Zhang H, Okamoto M, Panzhinskiy E, Zawada WM and Das M: PKCठ/midkine pathway drives hypoxia-induced proliferation and differentiation of human lung epithelial cells. Am J Physiol Cell Physiol 306: C648-C658, 2014. 